\title{
JOSÉ BERGAMÍN: O ESBOÇO BIOGRÁFICO DE UM INTELECTUAL ESQUECIDO
}

\author{
JOSÉ BERGAMÍN: THE BIOGRAPHICAL SKETCH OF A \\ FORGOTTEN INTELLECTUAL
}

Douglas de Freitas Pereira ${ }^{1}$

\begin{abstract}
RESUMO: Este artigo tem por objetivo esboçar uma biografia intelectual de José Bergamín, um dos escritores mais paradoxais da Espanha do século XX. A análise, a princípio, irá se deter nos primeiros anos de destaque do escritor durante a década de 1920 até a sua ascensão como um dos principais intelectuais espanhóis na década de 1930. Em seguida, o artigo irá tratar do exílio após o término da Guerra Civil Espanhola, sendo este dividido em dois momentos: de 1939 a 1954 e entre os anos de 1963 e 1970. Por fim, o artigo se voltará para os últimos anos de Bergamín na Espanha, onde morreu em 1983. Assim, a intenção do artigo é a de apresentar o escritor ainda pouco conhecido no Brasil, demonstrar a singularidade do seu pensamento, o lugar que ocupou na vida intelectual e o significado de ser escritor comprometido com a Segunda República Espanhola.
\end{abstract}

PALAVRAS-CHAVE: José Bergamín; Literatura Espanhola; História Intelectual Espanhola.

ABSTRACT: This article aims to outline an intellectual biography of José Bergamín, one of the most paradoxical writers in 20th century Spain. The analysis, at first, will focus on the writer's first years of prominence during the 1920s until his rise as one of the main Spanish intellectuals in the 1930s. Then, the article will deal with exile after the end of the Spanish Civil War, which will be divided into two moments: from 1939 to 1954 and between the years of

* Este artigo é fruto da pesquisa decorrente da dissertação de mestrado intitulada José Bergamín, Cayetano Córdova Iturburu e o engajamento intelectual antifascista na Espanha e na Argentina durante a década de 1930, desenvolvida na Universidade de São Paulo. Sua redação beneficiou-se de financiamentos da Coordenação de Aperfeiçoamento de Pessoal de Nível Superior (CAPES) e da Fundação de Amparo à Pesquisa do Estado de São Paulo (FAPESP). Agradeço ao Professor Max Hidalgo Nácher pela interlocução sobre os assuntos aqui tratados.

${ }^{1}$ Bacharel e licenciado em História pela Universidade Federal de Minas Gerais. Mestre e Doutorando em História Social pela Universidade de São Paulo. Email: douglasfreitas77@gmail.com 
1963 and 1970. Finally, the article will turn to Bergamín's last years in Spain, where he died in 1983. Thus, the intention of the article is to introduce a writer still little known in Brazil, demonstrate the uniqueness of his thought, the place he occupied in intellectual life and the meaning of being a writer committed to the Second Spanish Republic.

KEYWORDS: José Bergamín, Spanish Literature; Spanish Intellectual History

\section{Introdução}

Como uma biografia (ou neste caso, um esboço biográfico) pode ajudar na compreensão de um processo histórico? Os teóricos e críticos do gênero sempre ressaltam a tentativa falha dos biógrafos de tentarem imputar coerência e racionalidade na trajetória marcada por devires na qual o sujeito muitas vezes aparece como senhor do destino e desembocam naquilo que Pierre Bourdieu (2006) chamou de "ilusão biográfica". Às biografias também já foi concedido a função pedagógica por relatar as virtudes e feitos de grandes nomes. Há, porém, uma relação recíproca e permanente entre biografia e contexto, como ressaltado por Giovanni Levi (2006). Nesse sentido, a escrita biográfica permite a descrição do funcionamento das normas, assim como as suas incoerências, permitindo a averiguação das repartições desiguais do poder e as margens de ação dos indivíduos.

Pierre Bourdieu (2006, p.190) chama atenção para esse caráter social das biografias. Segundo ele, os atos biográficos "se definem como colocações e deslocamentos no espaço social, isto é, mais precisamente nos diferentes estados sucessivos da estrutura da distribuição das diferentes espécies de capital que estão em jogo no campo considerado”. Assim, uma trajetória individual só pode fazer sentido se compreendida toda a malha social na qual está inserido o indivíduo. Nobert Elias (1994), no estudo biográfico que fez sobre o músico Wolfgang Mozart, tentou demonstrar a sociologia envolta na criação de um gênio com a intenção de desmistificar a ideia da existência de um talento inato que elevaria alguns indivíduos acima de outros em diversos campos.

Para adentrarmos a trajetória biográfica de José Bergamín, é necessário partirmos de seu nascimento em Madri, no dia 30 de dezembro de 1895. Filho de Francisco Bergamín e Rosário Guiérrez López, era o caçula de treze irmãos. 
Seu pai foi um jurista que ocupou cargos públicos como o de catedrático de legislação mercantil na Escola Central de Comércio, também foi filiado ao Partido Liberal Conservador, pelo qual foi várias vezes ministro, ocupando cadeiras da Fazenda e da Instrução Pública. Entre suas obras mais relevantes estão livros sobre Economia Política e Direito Mercantil (PENALVA, 1985). Sua mãe era uma católica fervorosa de quem o autor diz ter herdado sua fé e religião, assim como sua formação poética (DENNIS, 2017).

Bergamín conta ter começado a escrever muito novo, com nove ou dez anos, mas, apesar disso, o escritor optou por não estudar literatura na Universidade de Madri por medo de se deparar com professores sem imaginação (DENNIS, 2017). Ele cursou direito, assim como o pai. O seu arcabouço teórico e literário iniciado ainda na juventude foi formado por escritores europeus, principalmente espanhóis, franceses, ingleses e alemães, a exemplo de Shakespeare, Byron, Júlio Verne, Menéndez Pelayo, Nietzsche, Goethe, dentre outros ${ }^{2}$.

Ainda na juventude, Bergamín teve contato com escritores anarquistas a exemplo de Kropotkin, Proudhon, Bakunin, Reclus e Herzen. O peso dessas leituras em sua formação intelectual é dúbio. O seu biógrafo, Gonzalo Penalva (1985, p.32), afirma de maneira um tanto vilipendiosa que elas teriam deixado o

\footnotetext{
${ }^{2}$ Em uma espécie de autobiografia entregue ao principal pesquisador da obra de Bergamín, Nigel Dennis, o escritor espanhol detalha essas influências literárias:

Mis primeras lecturas juveniles a las que toda mi vida he seguido fiel, fueron: Goethe (en francés, que aprendí a leer al mismo tiempo que el español), Julio Verne, Tolstoi, Ibsen, Heine, Shakespeare, Byron, Hugo... Y en español: La Celestina, casi todo Menéndez Pelayo, Bécquer (culto familiar andaluz), y Rubén Darío, Valle-Inclán, Felipe Trigo... Seguidamente, leí a Unamuno, Azorín, los Machado, Juan Ramón Jiménez... También en mis primeros años juveniles aprendí yo solo a leer el italiano, leyendo la Divina Comedia y el Decamerón (éste último lo había leído ya en español) y a D'Annunzio. Pero la preponderante influencia en mis años jóvenes fue la de la literatura francesa 'finisecular', desde el romanticismo al 'simbolismo': con predilección por Nerval y Baudelaire; más tarde por Gauthier. Guiado por Los raros de Rubén Darío y por la lectura de Rémy de Gourmont, mi mundo juvenil vivía esa literatura apasionadamente; y aquellas lecturas culminan na Gide y, sobre todo, en Barrès: este último es el que decisivamente influyó más en mí. Entretanto, eran mis lecturas fundamentales de juventud: Pascal, Ibsen, y los rusos - Tolstoi y Dostoevski: y sobre todos Nietzsche. A más de Goethe y Heine; más tarde, Novalis, al que leía por Maeterlink, que también fue importante lectura juvenil mía. En el fondo de todas estas lecturas de mi juventud, hay tres esenciales que apoyaron mi pensamiento para toda mi vida: los Diálogos de Platón, la Ética de Spinoza, y la Crítica de la razón pura de Kant (BERGAMÍN, apud, DENNIS, 2017, p. 7).
} 
escritor espanhol "às portas do suicídio" em 1919. Nigel Dennis (2017, p.9) literato que se dedicou aos estudos da obra de Bergamín, diz que tais leituras tiveram influência no "idealismo utópico" e no "senso de justiça" do escritor que unia tudo isso à sua fé cristã. Tais afirmativas aparentemente contraditórias parecem ter um pouco mais sentido quando comparadas, uma vez que Bergamín desenvolveu essa relação entre catolicismo e anarquismo no texto Por nada del mundo (anarquismo y catolicismo), escrito durante a Guerra Civil Espanhola, mas publicado posteriormente ${ }^{3}$. O autor, nesse texto, constrói uma crítica ao fascismo espanhol e à sua influência na Igreja, expondo aquilo que ele julgava ser a conduta que a Igreja deveria adotar. O anarquismo, no texto, ganha diversos sentidos, desde sinônimo de "bagunça" e "caos" até uma característica atribuída pelo autor a Deus, o qual Bergamín afirma que "às vezes parece anarquista" (BERGAMÍN, 1976). A predominância de certa aversão ao ideal anarquista no texto indica uma afirmação de Hortensia Campanella (2010) de que o autor abandonou essa ideologia ainda na juventude.

Apesar de muitos desses escritores citados por Bergamín estarem presentes em seus textos ao longo de sua vida, foi a partir da década de 1920 que ele estabeleceu os principais diálogos e interlocuções com outros autores. Também foi nesse período que o jovem escritor passou a participar de outros grupos intelectuais e ganhou mais espaço dentro da esfera pública espanhola, vindo a fazer parte de publicações de destaque no país e firmando contato com grandes nomes das letras naquele momento, algo que o ajudou a ocupar um lugar central entre a intelectualidade espanhola na década de 1930, e também dentro do movimento intelectual antifascista naquele país, como iremos analisar posteriormente.

Apesar do colocado no início do texto, acreditamos que seguir uma trajetória cronologicamente linear ajudará o leitor a se situar melhor no contexto histórico e consequentemente no impacto dos acontecimentos que de alguma forma reverberaram nas ideias e na produção do escritor madrilenho.

\footnotetext{
${ }^{3}$ Esse texto foi publicado em duas coletâneas, a primeira intitulada Detras de la cruz. Terrorismo y persecución religiosa en España de 1941 e El pensamiento perdido: paginas de la guerra y del destierro de 1976.
} 
Ao final do texto, acreditamos ser possível ter a compreensão, ainda que limitada, do que significava ser escritor defensor da Espanha republicana como também o próprio lugar ocupado por José Bergamín na história intelectual espanhola.

\section{A década de 1920 e os diálogos intelectuais}

A carreira de Bergamín como escritor começa de maneira oficial no início da década de 1920, quando publicou no periódico Indice, de Juan Ramón Jiménez. Também nesse período, ele, junto de Gómez de la Serna, funda as tertúlias no Café Pombo ${ }^{4}$, que foram bastante importantes para a inserção de Bergamín no meio literário espanhol. Em 1923, o jovem escritor publicou o seu primeiro livro, El cohete y la estrella, uma obra de aforismos que começava a delinear o seu estilo próprio. Também foi nessa década que Bergamín estabeleceu contato com Miguel de Unamuno, o escritor que foi, para muitos dos conhecedores de sua obra, a sua maior influência.

De fato, a presença de Unamuno nos escritos de Bergamín é bastante recorrente e, para além disso, existe um epistolário dos dois entre os anos de 1923 e 1935, reunido e publicado por Nigel Dennis em 1993, na qual a relação de admiração de Bergamín com Unamuno é bastante explicitada. Por sua vez, Unamuno também demonstrava certa simpatia com Bergamín. Exemplo disso é quando foi publicado El cohete y la estrella. A crítica não foi tão receptiva ao livro, o que gerou certa angústia em Bergamín, que escreveu uma carta para Unamuno, datada de 8 de janeiro de 1924, perguntando sua opinião sobre o livro. Essa carta, entretanto, não foi respondida, o que gerou em Bergamín certo temor de Unamuno não ter gostado de um aforismo que escrevera em sua homenagem, como demonstra em outra correspondência assinada em 9 de fevereiro do mesmo ano: "entre muchos silencios hostiles y comentarios fastidiosos por equivocados, esperaba con cierta impaciencia alguna palabra suya" e complementa expressando o temor já apontado anteriormente:

\footnotetext{
4 Essas tertúlias foram, provavelmente, as maiores e mais famosas do período, sendo extinguidas somente com o início da Guerra Civil Espanhola em 1936. Todavia, foram imortalizadas na pintura de José Gutiérrez Solana, intitulada: La tertulia del café de Pombo, exposta na coleção permanente do museu Reina Sofía em Madri.
} 
"Sentiría haberle herido, sin querer, con una alusión que acaso no expresa exactamente toda mi admiración y respeto" (BERGAMÍN, [carta 9/02/1924] 1993, p. 40).

Após essa segunda carta, Unamuno responde e comunica que escreveria uma resenha do livro, o que de fato ocorreu, sendo ela publicada na revista Nuevo Mundo, de 7 de março de 1924. Em um tom elogioso, Unamuno exalta bastante o livro definindo-o como uma obra de "germinativas afirmações". Unamuno chega até mesmo a fazer um paralelo entre a sua obra com a de Bergamín, afirmando que ambas eram reflexos de seus autores (UNAMUNO, 1924, n.p.). Segundo Nigel Dennis, como uma forma de agradecimento a essa generosa colaboração, Bergamín (1942, p. 88) dedicou o seu segundo livro ao escritor bilbaíno: "A Don Miguel de Unamuno místico sembrador de vientos espirituales".

Além dessas, outras passagens demonstram a grande consideração que ambos tinham um pelo outro, como quando Unamuno foi exilado em 1924 após se envolver em uma polêmica com o Rei Afonso XIII. Durante esse exílio, Unamuno se recusava a publicar e mesmo a ler qualquer coisa advinda da Espanha, já que o país sofria, segundo ele, com forte censura ${ }^{5}$. Bergamín, porém, conseguiu convencer o escritor bilbaíno a publicar uma das cartas que trocaram em 1928 na revista Carmen, de Gerardo Diego. Essa carta continha alguns poemas que Unamuno havia escrito durante o exílio e foram publicados com o pseudônimo "un poeta enigmático y solo"6 . Além de ser uma das poucas publicações de Unamuno na Espanha durante o exílio, esses poemas compuseram uma edição póstuma publicada com o título de Cancionero, o que torna essa uma passagem um tanto relevante (DENNIS, 1993).

Por passagens como essas e tantas outras, que muitos dos estudiosos da obra de Bergamín, a exemplo de Nigel Dennis, afirmam ser quase que obrigatório falar de Unamuno para tratar da obra e trajetória intelectual de José Bergamín. Fica clara uma relação de dependência de Bergamín com Unamuno,

\footnotetext{
${ }^{5}$ Ver cartas de 13/04/1926 e 20/04/1926 (BERGAMÍN, 1993, p. 67-69)

${ }^{6}$ Ver as cartas de 28/02/1928, 07/03/1928 e 24/03/1928 (BERGAMÍN, 1993, p. 73-77).
} 
de quem ele parecia precisar da aprovação e do reconhecimento. Por outro lado, essa relação concedeu a Bergamín a fama de discípulo e herdeiro mais importante do catedrático de Salamanca.

\section{0: de Cruz y Raya à Guerra Civil Espanhola}

Não seria nenhum exagero afirmarmos que José Bergamín viveu na década de 1930 o auge de sua trajetória intelectual. Naquela década, o autor ocupou posições centrais em diversas iniciativas, como na direção da revista Cruz y Raya, a principal publicação católica da Espanha naquele momento e, durante a Guerra Civil, foi presidente da Aliança Antifascista Espanhola e encabeçou o II Congresso de Intelectuais para a Defesa da Cultura, realizado em 1937. Esse período também marcou seu envolvimento mais direto com a política. Logo após o início da Segunda República em 1931, Bergamín ocupou um cargo no novo governo, mas saiu rapidamente. Alguns de seus textos também passaram a apresentar uma carga política maior, sobretudo a partir de Cruz y Raya.

O primeiro número de Cruz y Raya foi publicado em abril de 1933. A revista tinha como objetivo auxiliar na instrução católica, uma vez que, desde a emergência da Segunda República, a Espanha passou a se laicizar. Era, dessa forma, um periódico feito por católicos, mas também republicano, reunindo ambos os valores como afirmou o próprio Bergamín:

Cruz y Raya nacía en aquella República, diríamos que de aquella República y hasta que, para aquella República, identificándonos con ella, con su íntima lucha o agonía. Por eso, el primer SI de la revista fue para la República misma: fue decir si a aquella vida republicana naciente. Y al mismo tiempo, en consecuente decisión afirmativa, $\mathrm{NO}^{7}$ a quienes la negaban y combatían para destruirla. Por definición Cruz y Raya se afirmó a sí misma como católica y republicana (BERGAMÍN, 1974, p. VIII).

Para ajudá-lo, Bergamín recorreu a alguns dos grandes intelectuais da Espanha daquele momento, como Ortega y Gasset, Miguel de Unamuno, Antonio Machado e Manuel de Falla. O primeiro colaborou com um texto

\footnotetext{
${ }^{7}$ O "sim" e o "não" fazem referência ao subtítulo da publicação: "revista de afirmación y negación" representado pelos sinais de soma (+) e de subtração (-), sendo a revista para o seus editores "un sí, un no, una línea recta, un fin" (EDITORES, 1933, p. 9).
} 
publicado no sétimo número da revista em outubro de 1933 Unamuno e Machado, por sua vez, não colaboraram com textos para a revista, mas participaram de maneira mais indireta Machado, inclusive, chegou a colaborar com o Editorial Árbol, editora da revista. Já Falla participou de maneira mais incisiva, vindo a constar como um dos fundadores do periódico (BERGAMÍN, 1974).

A relação entre Falla e Bergamín, porém, acabou se tornando bastante conflituosa, sobretudo pelo fato de não concordarem com a concepção de catolicismo um do outro e com a forma como isso aparecia na revista. Falla tinha uma visão mais "tradicional" da religião católica e, para ele, Bergamín muitas vezes infligia o segundo mandamento, ou seja, tomava o nome de Deus em vão (FALLA [carta, 16/02/1935], 1995, p. 123-125). A essa acusação, Bergamín responde que sua intenção com a revista nunca fora a de fazer uma publicação fechada no catolicismo que levasse a sua mistificação, mas, sim, uma publicação substantiva, "con literatura, con filosofía, con investigación científica, con arte... De veras. Con todas las actividades espirituales del pensamiento, independientes y compatibles con la actividad religiosa de la fe y de la esperanza y de la caridad" (BERGAMÍN, 1995, p.131). Por fim, em

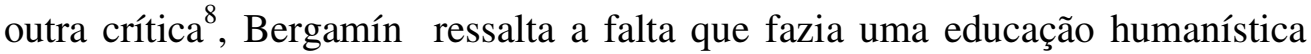
para a Espanha daquele momento, pois, o país vivia uma insensibilidade estética e moral entre aqueles que ele chamou de "massas de católicos ignorantes" (BERGAMÍN [carta, 04/09/1935] 1995, p. 144).

Além de editar, Bergamín também publicava em Cruz y Raya. No número de estreia, escreveu El pensamieto hermético de las artes. Nesse texto, Bergamín analisa a criação e a crítica de arte que para ele teria como origem o que ele chama de "pensamento puro" (BERGAMín, 1933, p. 45). A racionalidade artística é, para ele, hermética. Ganha papel fundamental na sua análise a figura do deus grego Hermes, que representa em sua interpretação tanto o "pensamento poético puro" e a "razão divina", como também atuaria

\footnotetext{
${ }^{8}$ Toda essa querela entre os dois intelectuais pode ser vista no epistolário de ambos reunido e publicado por Nigel Dennis (1995).
} 
como guia para o inferno (BERGAMÍN, 1933). Essa figura de Hermes como guia das almas para o inferno é, segundo Walter Otto (2003, p. 65), uma representação posterior aos escritos de Homero chamado de Hermes Psicopompo. Bergamín também utiliza a figura do deus grego no texto $L a$ importancia del demonio publicado no quinto número de Cruz y Raya. Nesse texto, Hermes é interpretado como a "representação unificada do demônio", sendo diretamente relacionado ao demônio cristão (BERGAMÍN, 1933c). O que Bergamín faz nesses dois textos é "uma leitura hermética e cristianizada do mito de Hermes", porém, se considerarmos o período da produção desses textos e, também, os objetivos da revista Cruz y Raya, onde foram publicados, ambos ganham sentido de crítica subjetiva ao processo de laicização que estava em curso na Espanha (PEREIRA, 2019). Isso fica mais claro levando-se em conta um terceiro texto publicado no terceiro número de Cruz y Raya, intitulado $L a$ decadencia del analfabetismo. Nesse escrito, Bergamín defende a existência de dois tipos de cultura, a que ele chama de literal e outra de espiritual. Para o escritor, essa cultura literal, quando aplicada em separado da espiritual, ou seja, através de uma educação laica, faria com que o sujeito passasse a entender tudo ao pé da letra e, consequentemente, levaria a perda da imaginação e à falta de conexão com o sagrado (PEREIRA, 2019). Para ilustrar essa diferença de conhecimentos, Bergamín cita uma passagem na qual Cristo, ainda criança, vai até um templo onde vários doutores em diversas áreas ensinavam conhecimentos "literais" e, ali, os ensinou conhecimentos espirituais, mas nenhum deles foi capaz de assimilar esse aprendizado. Ele, então, afirma que Cristo foi crucificado por ser analfabeto:

Por eso al condenarle a muerte, por analfabeto, le crucificaron literalmente, esto es, al pie de la letra o de las letras, colocando sobre su cabeza un cartel o letrero en el que el literato Pilatos hizo escribir ciertamente: Yo soy el Rey de los Judíos; y mandó escribir esto para demostrarles a todos ellos que habían tomado a Cristo al pie de la letra en lo que había dicho, y que, por tomarlo de este modo, literalmente, lo crucificaban. Debajo de ese INRI literal, Cristo entregó el espíritu; dando una gran voz, dice al apóstol, en un grito: divinamente y humanamente analfabeto. $\mathrm{Al}$ pie de la letra muere siempre el espíritu crucificado (BERGAMÍN: 1933B, p. 71). 
Dessa maneira, percebemos a laicização era um objeto de crítica central para o autor que a constrói por meio de um contraponto feito ao relacionar a figura do demônio a do deus Hermes, representante, para ele, do "pensamento puro" e "racional" (literal) e a de Cristo com o analfabetismo e ao conhecimento espiritual. Nessa linha, Bergamín também se aproxima da tradição cultural popular da Espanha que era bastante marcada pelo catolicismo, ao mesmo tempo que demonstra certa contradição, pois a educação laica era um valor presente na constituição da Segunda República Espanhola da qual ele era defensor.

Em outros textos publicado em Cruz y Raya, Bergamín desenvolveu também sua crítica quanto a apropriação que alguns partidos, tanto à direita quanto à esquerda, fizeram da República e como isso era prejudicial ${ }^{9}$. Destacamos, porém, a união entre catolicismo e marxismo feita pelo escritor espanhol que faz com que ele possa ser considerado um católico bastante distinto da grande maioria naquele momento. No texto publicado em julho de 1935, no exemplar de número 27 de Cruz y Raya, intitulado Hablar en Cristiano, Bergamín elogia André Gide e a sua apresentação no Congresso Internacional de Escritores para a Defesa da Cultura, realizado em Paris, naquele ano. Para ele, Gide "hablava en cristiano", isto é, se comunicava com clareza. Nesse texto Bergamín destaca da fala de Gide, dentre outras coisas, o seu caráter internacionalista e o coloca em oposição ao nacionalismo fascista, afirmando que ele pretendia ser "profundamente internacionalista sem deixar de ser profundamente francês" (BERGAMÍN, 1935, p. 74). Gide teria afirmado também que buscava ser demasiadamente individualista "com o assentimento comunista e com a ajuda mesma do comunismo" (BERGAMÍN, 1935, p. 74). Essa afirmativa partia da ideia de que "o comunismo restitui ao indivíduo a sua fertilidade”, frase que atribui a Malraux (BERGAMÍN, 1935, p. 74). Gide ainda teria defendido que o comunismo deveria ajudar o desenvolvimento individual, por ser uma ideologia de oposição às injustiças sociais.

\footnotetext{
${ }^{9}$ Para uma análise mais detida sobre esse assunto ver: PEREIRA, 2019.
} 
O tom um tanto paradoxal da fala de Gide parece ter inspirado Bergamín que, a partir dela, vai fazer um paralelo entre comunismo e cristianismo, utilizando de conceitos típicos do vocabulário comunista como "homem novo" e "revolução permanente":

¡El hombre nuevo! ¡Con qué seguridad de trazo, con qué primor de estilo se dibuja a sí mismo el que quiere enseñarle eso al hombre nuevo: a que lo sea, a que se dibuje a sí mismo! [...] Pero acaso sin ver, o sin decirnos, que el que se dibuja a sí mismo es ya un hombre nuevo: el hombre nuevo. Que el hombre, cuando es hombre, siempre es nuevo. Y que el hombre sea siempre nuevo es una de las primeras verdades del cristianismo. Del cristianismo no histórico, ni evolutivo o progresivo: del cristianismo revolucionario permanente. El cristianismo nos dice del hombre que se puede novar o renovar siempre, haciéndose de nuevas. Pues esto, y acaso no otra cosa, quiere decir evangelizarse (BERGAMÍN, 1933, p. $81)$.

Nigel Dennis (2017, p. 172) afirma que tanto Bergamín quanto Gide esperavam a "afirmação e renovação do indivíduo", o primeiro por meio do catolicismo e o segundo pelo comunismo. Bergamín emprega o termo "revolução permanente" de maneira a referenciar tanto o sentido mais universalista da corrente trotskista, como a ideia de que existe apenas uma revolução que acontece de maneira perpétua no tempo, concepção esta que Hanna Arendt atribuiu a Proudhon (PEREIRA, 2019, p. 77). Assim, Bergamín parece evidenciar uma crença de que a saída, ainda que revolucionária, só seria possível, ou pelo menos desejável, se passasse pelo cristianismo.

Com o início da Guerra Civil Espanhola, Cruz y Raya encerrou suas atividades e Bergamín passou a se envolver mais com a causa antifascista. Um dos principais acontecimentos no âmbito intelectual do período no qual o escritor estava envolvido foi a realização do II Congresso Internacional de Escritores para a Defesa da Cultura. Esse congresso reuniu aproximadamente cento e vinte participantes, dentre eles nomes conhecidos como Octavio Paz, Pablo Neruda, Julien Benda, Jef Last, para citar apenas alguns. A fala de Bergamín no congresso voltou-se para criticar os intelectuais que se eximiram de se pronunciarem a respeito do fascismo e da guerra na Espanha. Sua crítica partia da figura de Hamlet que, para ele, significava a "caricatura trágica do 
intelectual" marcado pela indecisão, um intelectual vacilante que buscava se isolar como "uma tartaruga em sua carapaça". Esse comportamento seria, segundo o escritor, uma máscara do medo, mas o medo da vida e não da morte e, assim, ressalta:

La cobardía no es miedo a la muerte, es miedo a la vida. Y ese intelectual blindado a toda prueba de comunión o comunicación humana, vive, se pudre en sí mismo y de sí mismo: se encierra faraónicamente en ese inconsciente empeño suicida, se pudre e momifica en vida, encerrándose en su propia tumba (BERGAMÍN, 1937b, p. 31-32).

Nesse período, Bergamín intensificou as suas críticas aos católicos e ao comportamento da Igreja, não apenas na Espanha, sobretudo pelo apoio que a instituição deu ao fascismo. Além disso, o Papa Pio XI publicou uma encíclica atacando o comunismo e o responsabilizando pelo conflito espanhol. O Papa classificou o comunismo como um "pseudo-ideal de justiça, de igualdade e de fraternidade no trabalho" que, desse modo, "impregna toda a sua doutrina e toda a sua atividade dum misticismo hipócrita, que as multidões seduzidas por promessas falazes e como estimuladas por um contágio violentíssimo lhes comunica um ardor e entusiasmo irreprimível” (PIO XI, 1937, n/p.). O pontífice ainda alegou que o comunismo disseminava o ódio e, no caso da Espanha, ele afirmou que a "peste e o flagelo comunista" produziram todas as desgraças e desencadeou "uma violência furibunda e irrompeu em funestíssimos atentados". Pio XI também acusou o comunismo de perseguição cristã no país:

E não se limitou o furor comunista a trucidar bispos e muitos milhares de sacerdotes, religiosos e religiosas, alvejando dum modo particular aqueles e aquelas que se ocupavam dos operários e dos pobres; mas fez um número muito maior de vítimas em leigos de todas as classes, que ainda agora vão sendo imolados em carnificinas coletivas, unicamente por professarem a fé cristã, ou ao menos por serem contrários ao ateísmo comunista. E esta horripilante mortandade é perpetrada com tal ódio e tais requintes de crueldade e selvajaria, que não se julgariam possíveis em nosso século (PIO XI, 1937, n/p).

Bergamín considerou essa posição da Igreja como uma usurpação da "verdadeira religião" por impostores que estavam causando a desfiguração do catolicismo (BERGAMÍN, 1976). Com relação aos católicos espanhóis, o autor 
afirma que estavam atuando como "propagandistas da guerra", perdendo assim a razão de ser da religião que os seus representantes deveriam encarnar (BERGAMÍN, 1976). Consideramos que essa tomada de posição evidencia ainda mais a aversão de Bergamín ao catolicismo mais conservador, como vimos antes com seu desentendimento com Falla. A revolução que ele defendia passava pela ruptura com bases arcaicas da sociedade espanhola, como a monarquia. A defesa da república implicava, para ele, uma vivência mais progressista do cristianismo que deveria se descolar dessas bases conservadoras.

A Guerra Civil Espanhola foi um evento traumático e, dentro da perspectiva cristã de Bergamín, apoiar o derramamento de sangue, ainda que de fascistas, poderia ser interpretado como contradição. Segundo María Teresa S. M. Fernández (2015), o escritor espanhol lidava com a sua "consciência cristã" por meio da compreensão do martírio espanhol. Nessa perspectiva, também a crença numa transcendência da vida mundana o ajudava. No texto La mascara de sangre, tiempo y drama, ele desenvolve uma reflexão a respeito do sofrimento que tinha tomado a Espanha durante a guerra (BERGAMÍN, 1937a). Bergamín traça um diálogo com Heidegger e a sua concepção de ser-para-amorte, mas, no seu entendimento, a completude não viria na morte, mas na sua transcendência. Nessa concepção, o escritor retoma Hamlet e a sua icônica frase “ser ou não ser?", que deveria ser o questionamento que todo indivíduo deveria se fazer: "ser ou não ser cristão?", em outras palavras, escolher entre a completude na morte ou transcendê-la? A escolha pela esperança da segunda opção resolveria o "impasse e levaria à consciência de que toda morte é um fim de mundo, um juízo final, um apocalipse, fazendo dele um 'contemporâneo de sua morte e extemporâneo de sua vida"” (PEREIRA, 2019, p. 157). Dessa mesma maneira, "o povo espanhol naquele momento, atuava como mártir, entregando seu sangue para um bem maior e comum, não apenas da própria Espanha, mas de todo o restante do mundo que temia o avanço fascista" (PEREIRA, 2019, p. 157).

\section{O exílio}


Após o término da Guerra Civil Espanhola, Bergamín foi para o exílio. Primeiro se dirigiu para o México, onde ficou até 1946, e em seguida foi para a Venezuela em uma estadia que durou menos de um ano. Depois foi ainda para o Uruguai, onde permaneceu até 1954. Nesse mesmo ano regressou à Europa, indo primeiro para a França e posteriormente para a Espanha, em 1958. Permaneceu em seu país natal até 1963, quando foi novamente expulso, regressando brevemente ao Uruguai, em 1964. Nesse mesmo ano volta para França, se estabelecendo em Paris até 1970, quando regressa em definitivo para a Espanha, onde falece em 1983.

Muitos dos espanhóis exilados viam na Segunda Grande Guerra a continuidade da Guerra Civil que tomou a Espanha por três anos. Em um primeiro momento, depositaram suas esperanças na possibilidade de vitória dos Aliados atingir o governo de Franco, o que levou muitos deles a se alistarem em batalhões dos países que elegeram como destino, a exemplo de França e União Soviética (BEEVOR, 2005). A reconfiguração política, porém, acabou com a esperança dos republicanos de retornar à Espanha, uma vez que, já no contexto de Guerra Fria, o governo espanhol se aproximou dos Estados Unidos e garantiu a não-intervenção ao ceder território para a construção de bases militares estadunidenses (FORNERÓN, 2015).

O exílio espanhol atravessou mais de três décadas e, segundo Ivan Martucci Fornerón (2015), pode ser dividido em três momentos: o primeiro marcado pela noção de que o exílio seria provisório e após uma vitória dos Aliados os exilados poderiam voltar ao seu país. O segundo momento começa para o autor na década de 1950, quando a esperança existente até então é golpeada pela aproximação do governo espanhol do estadunidense, como citado anteriormente. Por fim, o terceiro abarcaria parte dos anos 1960 até os primeiros anos da década de 1970, e ali a concepção que prevalece é a de um exílio ininterrupto. Segundo Fornerón (2015, p. 26): “O exílio, aqui, não é só o exílio dos exilados, mas também o exílio da história", pois o "momento em que os desterrados se veem diante da possibilidade do apagamento, já que à expulsão política de 1939 agora soma-se a expulsão da história, cumpre pensar 
o que é essa história e o seu tempo". Assim, a análise da produção dos escritores espanhóis exilados torna-se reveladora dos sentidos e dos significados que o exílio teve para eles ${ }^{10}$.

A vivência do exílio por Bergamín também não foi muito diferente a de outros intelectuais espanhóis. Seu período no México foi bastante produtivo, já que publicou livros, como Disparadero español, Detrás de la cruz e El pozo de las angustias, e também esteve à frente da revista España Peregrina e ainda foi editor no Editorial Séneca. Segundo Hortencia Campanella (2010), a morte da sua esposa, a sua filha ter contraído uma doença grave e a impossibilidade de poder retornar à Espanha após o término da Segunda Guerra, transformaram-se em angústias que tomaram o escritor. Após essa sucessão de acontecimentos, Bergamín opta por deixar o México e ir para a Venezuela onde residia um de seus irmãos. Esse é um dos períodos menos conhecidos de sua trajetória, já que mesmo a documentação existente segue sem análise. Em 1947, chegou ao Uruguai onde atuou como professor de intelectuais que viriam a ser conhecidos como a "geração de 45" ou "geração de Marcha". Bergamín lecionou para nomes como Ángel Rama, Amanda Berenguer, Ida Vitale, Guido Castillo, José Pedro Díaz, Carlos Maggi, Manuel Flores Mora, entre outros. Alguns nomes dessa mesma geração foram críticos a ele, a exemplo de Mario Benedetti, Idea Vilariño e Emir Rodríguez Monegal (CAMPANELLA, 2010, p. 94).

Durante seu exílio Bergamín escreveu diversos textos, poemas e também alguns livros, dentre os quais destacamos o Fronteras infernales de la poesía, publicado em 1959. Nesse livro, Bergamín se questiona sobre a possibilidade de uma experiência poética do inferno. $\mathrm{O}$ autor busca tal resposta nas obras de nove escritores: Sêneca, Dante, Fernando de Rojas, Shakespeare,

\footnotetext{
${ }^{10}$ Ivan Matucci Fornerón elege três escritores exilados para a sua análise: Luis Cernuda, Emilio Prados e Max Aub, respectivamente. Todos, assim como Bergamín, pertencentes a chamada "geração de 27. Segundo Fornerón, o conceito de "geração de 27" surgiu em referência a um evento organizado por José María Romero Martínez, em homenagem ao poeta Luis de Góngora no Ateneu de Sevilha em 1927. Porém, ressalta que essa é uma leitura limitada do grupo com problemas de ordem cronológica e histórica (FORNERÓN, 2015, p. 15-16). Bergamín, por sua vez, referia-se a tal geração como "constelação republicana" em referência a essa variedade e também pela atuação do grupo durante a Segunda República (CAMPANELLA, 2010, p. 98).
} 
Cervantes, Quevedo, Sade, Byron e Nietzsche, respectivamente. Ele os divide em quatro duplas mais Nietzsche como explica:

En este libro encontrará el lector otras cuatro parejas inmortales y Nietzsche. Séneca, Dante, Rojas, Shakespeare, Cervantes, Quevedo, Sade, Byron, fueron los ocho en que tuve puestos mis ojos, sintiendo en mí, como una sola, sus miradas. Cuatro parejas de sombras infernales que al darse y quitarse la razón entre sí, al dármela o quitármela, parecería que van acompañadas de Nietzsche, que acompañó su soledad con aquellas otras. También estas cuatro parejas infernales y Nietzsche acompañan la mía: las mías. Con estos nueve me parece que puedo yo entrar en explicaciones cuando camino largo tiempo en solitario. "Diga lo que diga y haga lo que haga: sea lo que sea lo que imagine para mí o para los demás"... Y "que me perdonen los vivos si son ellos los que me parecen como sombras". En estos nueve siento verdaderamente una vida eterna. Yo tampoco les he regateado mi propia sangre (BERGAMÍN, 1959, p. 7).

Um dos sentidos de inferno que a obra apresenta é o do exílio, representado também na figura da caminha solitária da citação acima. A ideia de fronteira apresentada no título é que guia os ensaios do autor, que defende que a poesia é fronteiriça a morte e, por esse motivo, é que ela pode responder às perguntas: “¿dónde está el infierno?, ¿más allá o más acá de la muerte?”. A resposta poética, por sua vez, traria tanto a ideia de "Infierno como realidad de verdad y como ilusión de mito: sin que ninguna de estas dos caras, aparentemente opuestas, se contradigan” (BERGAMÍN, 1959, p. 9-10). Junto a esses questionamentos vem outro, o de o inferno ser algo de outro mundo, deste ou de ambos e, nesse caso, onde estaria o inferno? Essas perguntas são também questões existências e fazem relação tanto à crença religiosa do escritor espanhol como aos conflitos internos e possíveis desventuras que viveu no exílio. O próprio conceito de fronteira remete à imagem de limite e início, de divisa e mesmo de "entre-lugares".

O inferno ganha sentidos diferentes também no decorrer do livro. Segundo Bergamín, na tragédia de Sêneca o inferno tem sentido de esperança que é manifestada como aquilo que resta ao herói vencido: "La única esperanza que le queda entonces al hombre heroico es la esperanza del Infierno, que con ese grito atroz, verdaderamente atroz, nos expresa: ¡Devuélveme el Infierno!” 
(BERGAMÍN, 1959, p. 31). Dessa maneira, o autor expressa que há algo pior que o inferno, a esperança dele e compara tal ausência do inferno, seja após a morte ou em vida, com uma espécie de limbo. Nesse sentido, acreditamos ser possível traçar um paralelo dessa "esperança" de ter o inferno de volta com o desejo do escritor de retornar à Espanha que, no regime franquista, era para ele infernal. Dante, por sua vez, converte vida em morte e morte em vida, segundo Bergamín, pois a "nova vida" começaria com a morte e, "a partir de este límite, el poeta se nos presenta como un desterrado del mundo, y no sólo de Florencia. Desterrado de la vida: de esta vida. El sentido espiritual de su destierro se nos hace doblemente significativo" (BERGAMÍN, 1959, p. 37). Torna-se inevitável em passagens como estas não relacionar à ideia de desterro referente tanto a morte como a uma nova vida com a própria trajetória de Bergamín. Dante, assim como Sêneca, responde para Bergamín a questão de "onde está o inferno" e a resposta é: "en el hombre mismo, dentro del hombre, que es la morada de la muerte (y el Infierno no es otra cosa que ésa: la viva morada de la muerte)" (BERGAMÍN, 1959, p. 46-47). Nesse sentido, se para uma nova vida era necessário "morrer", aqui alegorias entendidas como um recomeço no exílio, Bergamín manteve-se como um fantasma, uma assombração presa à Espanha republicana que já não existia.

Nos ensaios dedicados a Fernando de Rojas e Shakespeare, Bergamín apresenta concepções como o "inferno amoroso" e o "inferno interior" dentro das peças desses autores, vindo a classificar as obras de Shakespeare como “obscuras" e "sangrentas". Cervantes, por sua vez, é considerado uma obra "iluminada", entretanto, chama atenção, a solidão abordada pelo autor na figura de Don Quixote: "La soledad humana y divina de nuestro Don Quijote, es esa soledad imposible del hombre sin Dios (BERGAMÍN, 1959, p. 117)”, porém conclui que "El hombre no está nunca solo: o está con Dios o está con el Diablo" (BERGAMÍN, 1959, p. 119). Bergamín ainda apresenta a ideia de serpara-a-morte de Heidegger aplicada a Don Quixote, cuja realidade ele considera voltada para a morte: 
Si aplicamos ahora a la estupenda figuración dialéctica cervantina una fórmula post-unamunesca ${ }^{11}$, la de la metafísica heideggeriana, veremos que esa ambigua equívoca, paradójica, realidad quijotesca, es la realidad de verdad - como tradujo García Bacca - del hombre mismo: el ya tan repetido ser en el mundo, ser con los demás, y ser para la muerte. La realidad de Alonso Quijano, para ser o hacerse verdadera, tiene que doblarse, o desdoblarse, de la de Don Quijote: en la vida, en el mundo, con los demás y para la muerte; pero justa, exactamente, para la muerte, hasta la muerte y para la muerte (BERGAMÍN, 1959, p. 119).

No ensaio sobre Quevedo, Bergamín aponta o problema moral como uma experiência "humana do inferno", fazendo referência ao uso desses problemas por Quevedo em sua obra. Bergamín classifica como "burlescas" as representações feitas pelo autor que atuariam como uma espécie de zombaria com tendências pagãs da ideia de "inferno verdadeiro", Quevedo, assim, teria chocado os delatores e denunciantes religiosos de sua época (BERGAMÍN, 1959, p. 127-128). Ainda nessa chave moral, o escritor espanhol evoca a relação entre julgamento e morte, relacionando também com a conhecida passagem bíblica do livro de Matheus: "não julgueis, para que não sejais julgados". Nesse sentido, afirma Bergamín: "no somos juzgados los hombres porque morimos: morimos porque somos o fuimos juzgados. Es el juicio, el acto de juzgar, el que nos mata quitándonos, por la razón, por la pasión, la verdad inmortal de la vida" (BERGAMÍN, 1959, p. 132-133). Por fim, Bergamín comenta um terceto de Quevedo, retirado do poema Erato que trata de um amante desterrado tomado pela tristeza que se torna bastante revelador, também, do desterro do escritor madrilenho, como pode ser notado:

\footnotetext{
${ }^{11}$ Acreditamos que Bergamín faz referência a uma ideia defendida por Antonio Machado por meio de seu personagem Juan de Mairena, especificamente no texto Miscelánea apócrifa publicado na revista Hora de España em janeiro de 1938. Nesse texto, Machado trata da filosofia alemã e especificamente de Heidegger e aponta para uma precedência das ideias do filósofo alemão pelo próprio Machado e também por Miguel de Unamuno. Machado destaca que: [...] Don Miguel de Unamuno que, dicho sea de paso, se adelanta en algunos años a la filosofía existencialista de Heidegger, y que, como Heidegger, tiene a Kierkegaard entre sus ascendientes, saca de la angustia ante la muerte un consuelo de rebeldía cuyo valor ético es innegable. Donde Heidegger pone un sí rotundo de resignación, pone nuestro don Miguel un no casi blasfematorio ante la idea de una muerte que reconoce, no obstante, como inevitable [...] (MACHADO, 1938, p. 12-13). Essa ideia também foi defendida e divulgada por María Zambrano que publicou excertos desse texto de Machado na revista argentina Sur em março de 1938. Ver: (MACHADO, 1938, p. 7-16) e (ZAMBRANO, 1938, p. 85-86).
} 
Aquí, para morir, me faltó vida; allá, para vivir, sobró cuidado: fantasma soy en penas detenida. ¿Qué admirable este otro terceto quevedesco, también final, también implacable juzgador y condenador de la vida, de su propia vida! Fantasma detenido en penas y pesares: preso en cadenas de penosos, apesadumbrados pensamientos. Así nos dice el poeta de sí mismo (BERGAMÍN, 1959, p. 137).

A figura do fantasma também foi utilizada por Bergamín para se referir a si mesmo em seu exílio, como declarou em uma entrevista dada a Juan Cruz do jornal El País em 18 de abril de 1978: “¿Si alguna vez me sentí exiliado? Me sentí como un fantasma, y de hecho lo fui oficialmente en Francia, cuando se decidió que en efecto yo era jurídicamente inexistente""12 (BERGAMÍN, 1978, n/p). Essa ideia também está presente no poema Volver publicado em 1958, quando o escritor retorna para a Espanha, que analisaremos mais à frente. Porém, como já ressaltamos, acreditamos estar diretamente relacionada à incapacidade do escritor madrilenho de se desligar por completo da Espanha republicana na qual ele depositou esperanças e expectativas.

Marquês de Sade e Lorde Byron autores os quais Bergamín ironicamente chama de "Marquês Divino" e "Lorde Infernal", figuram, para ele, dois lados da poesia. O primeiro como um grande poeta cuja influência não era assumida ou revelada e o segundo como um poeta sempre referenciado. Sade por meio do "racionalismo", exporia seus desejos mais perversos e infernais de maneira bastante crua. Byron, por outro lado, o faria com a máscara de Don Juan. Ambos seriam, assim, facetas de uma mesma experiência infernal.

As definições e descrições infernais, feitas até aqui, foram para Bergamín, "experiência humana moral da poesia", não porque a poesia seja essencialmente boa, má, moral, imoral ou ainda, amoral; mas, sim, porque a criação poética humana, seja ela infernal ou celestial e mesmo com pretensões diabólicas ou divinas, não podem deixar de ser morais sem deixarem de ser humanas, e é nesse sentido que Bergamín evoca a Nietzsche. Bergamín chama Nietzsche de anticristão, porém, para ele, aqueles que são moralmente

\footnotetext{
${ }^{12}$ Bergamín aqui se refere ao fato de ter saído da Espanha em 1963 sem seus documentos, passagem que iremos abordar mais à frente.
} 
hipócritas não deveriam ler o filósofo alemão, pois seriam incapazes de compreender o "grito desgarrador de espanto", assim como o descreveu Blake. O inferno nietzschiano seria o inferno "de verdade" e "da verdade":

Nietzsche creía en el Infierno; y en un Infierno eterno. Porque creía en el Infierno de verdad: el Infierno de la verdad. En el eterno retorno trágico, infernal. Y creía, suprema paradoja, en que el hombre puede ser superado, creía en que el hombre es algo que debe ser superado, divina o diabólicamente: trágicamente (BERGAMÍN, 1959, p. 203).

Esse inferno eterno seria um inferno sem esperanças, um inferno "feito pelo primeiro amor", pelo "conhecimento supremo" e pelo "poder divino". Bergamín conclui por fim, que a maior virtude do pensamento nietzschiano para suas questões poético-infernais é o fato dele abarcar a poesia no seu sentido total, afirmando que aquilo que os homens encontram nas coisas não é nada além daquilo que eles mesmos puseram nelas. Ele encerra seu texto novamente se questionando sobre o inferno e, de certa forma, reafirmando o seu catolicismo por meio de Nietzsche, ao dizer que "parecería que Nietzsche nos clavase en el corazón trágicamente, como un grito, su propio dilema: o el Infierno o la Cruz (BERGAMÍN, 1959, p. 216). O inferno entendido como alegoria do exílio teria também o cristianismo como contraparte, como sustentáculo não só moral, para continuar e superar o tormento.

Em 1958, Bergamín retorna à Espanha depois de quase vinte anos no exílio, mas segundo Yasmina López (2015), esse retorno não significou o fim da agonia do desterro e não teria sido nenhum pouco fácil, pois, além de ter que refazer sua vida após anos fora, o escritor espanhol não deixou de lado seu posicionamento crítico com relação à política e à sociedade, o que culminou em um segundo exílio em 1963. De fato, o retorno do autor parece ter tido sabor um tanto agridoce para ele, que afirma isso no texto El anteísmo español de Buñuel, publicado originalmente no jornal El Nacional, no dia 13 de julho de 1961. O autor afirma que:

El español que vuelve a España tras largos años separados de ella; y más si estuvo alejado, desterrado de su suelo por razones espirituales, morales, políticas... siente, al volver, ese contacto con su tierra viva como algo que le devuelve fuerzas, que le da nueva realidad, como si se recuperase a sí 
mismo. Yo lo sé por experiencia propia. Sentí, al sentir España de nuevo, en su tierra, en su luz, en su aire... como si resucitase en ella: como si hubiese dejado de ser un fantasma (ilusión peligrosa siempre). Cuando antiguos amigos, en el destierro (en América, en Francia), me aconsejaban que no volviese, suponiendo que aquí podrían tratar de enterrarme vivo (cosa muy cierta y ya experimentada también por mí), yo les respondía: "prefiero ser un enterrado vivo que un desterrado muerto". Porque tenía, tuve en mi destierro físico y espiritual - la impresión tristísima de que se me iban acabando las fuerzas para aquella agonía; y que tenía que volver a España para seguir agonizando en ella; para que todo lo pasado adquiriese sentido verdadero para mí y para los demás españoles que pudiera tenerlo. Y así ha sido, así es. O yo así lo creo (BERGAMÍN (1961b), 1984-85, p. 87$88)$.

Baseando-se nisso, Yasmina López se questiona da possibilidade do retorno do exilado, pois, segundo ela, o exílio espanhol deve ser entendido não com uma experiência concreta, mas como consciência de uma ausência definitiva (2015, p. 153). No caso de Bergamín, acreditamos que essa impossibilidade de retorno foi real, pois a Espanha que deixou quando partiu para o exílio e com a qual que sonhou e almejou retornar, a Espanha Republicana, não existia mais. $\mathrm{O}$ autor, porém, tinha consciência disso, uma vez que afirmou que "una España que pienso y sueño todavía viviéndola como algo que merece ser superado" (BERGAMÍN (1961a), 1984-85, p. 84).

Esse sentimento é expresso em recorrentes publicações do escritor madrilenho nesse período. Outro exemplo é o poema anteriormente citado, Volver, publicado na revista Índice, de Madri em 1958. Nesse poema Bergamín afirma que não buscava o passado, mas sentia a necessidade de estar na sua terra natal, de deixar de ser um desterrado, um fantasma:

Volver no es volver atrás.

Lo que yo quiero de España no es su recuerdo lejano: yo no siento su nostalgia. Lo que yo quiero es sentirla: Su tierra, bajo mi planta; su luz, arder en mis ojos quemándome la mirada; y su aire que se me entre hasta los huesos del alma. 
Volver no es volver atrás.

Yo no siento la añoranza: que lo que pasó no vuelve, y si vuelve es un fantasma. Lo que yo quiero es volver sin volver atrás de nada.

Yo quiero ver y tocar con mis sentidos España, sintiéndola como un sueño de vida, resucitada.

Quiero verla muy de cerca, cuerpo a cuerpo, cara a cara: reconocerla tocando la cicatriz de sus llagas. Que yo tengo el alma muerta, sin enterrar, desterrada: quiero volver a su tierra para poder enterrarla. Y cuando la tierra suya la guarde como sembrada, quiero volver a esperar que vuelva a ser esperanza. Volver no es volver atrás: yo no vuelvo atrás de nada.

(BERGAMÍN (1958), 1984-85, p. 96-97)

Durante o período que esteve na Espanha após o exílio, Bergamín teceu críticas ao governo e a alguns intelectuais falangistas apoiadores do regime franquista. Isso fez com que alguns acusassem-no de comunista, resgatando seu passado durante a Guerra Civil e mesmo o ameaçando de morte. Segundo Roselyne Chenu (2015, p. 235) as ameaças vinham por telefone e pela imprensa dita "anônima". Nessas ameaças, exigia-se que Bergamín apenas se calasse e obedecesse. Entretanto, como ressalta Chenu, deveriam conhecê-lo muito mal para fazerem tal exigência. Bergamín responde a essas ameaças em um texto publicado no jornal El Nacional no dia 30 de abril de 1963. Nesse texto, o escritor espanhol destaca uma frase de Menéndez Pelayo que diz "el que queiera ver mi muerte/ traiga una luz encendida" e ressalta que "todavía, y cómo, por estarlo, me he de morir tan solo cuando Dios quiera. Y no sé si de muerte corta o larga - "perezosa y larga"” (BERGAMÍN (1963), 1984-85, p. 94). Avisado que poderia ser preso, Bergamín recorre a embaixada do Uruguai e no dia 30 de novembro, com salvo-conduto válido apenas para aquela data, 
com ajuda do embaixador uruguaio, ele consegue embarcar para o país cisplatino (CHENU, 2015, p. 237). A permanência de Bergamín no Uruguai foi curta e poucos meses depois estava em Paris novamente. A saída de Bergamín às pressas da Espanha fez com que ele chegasse no Uruguai e posteriormente na França, sem nenhum documento. Por esse motivo, o autor afirma que "cuando llegué a París de mi segundo exilio de España, y me convertí no ya en un refugiado político sino en un proscrito, por no tener documentos de identidad que el gobierno español me había negado" (BERGAMÍN apud. CHENU, 2015, p. 233).

Bergamín, mesmo depois de voltar para a Espanha, ainda continuava se considerando um peregrino, afirmando que sentia cada vez mais "peregrino en mi patria. Como un extraño en ella: no a ella. Y no por sus tierras y sus mares y sus cielos, sino por sus gentes" (BERGAMÍN (1963), 1984-85, p. 92). Esse estranhamento com as pessoas de seu país mostra não apenas a mudança pela qual o país passou nos anos do franquismo, mas também a mudança que ele sofreu no exílio e seu desejo de encontrar uma Espanha que ficou no passado. São sentimentos que ele sintetiza no pequeno poema que encerra o texto, que escreveu em resposta às ameaças que sofreu quando voltara para o seu país:

\footnotetext{
De una España Peregrina, ¿qué le queda al pensamiento que no sea convencimiento de que cree lo que imagina? Cuando el corazón se inclina a ese fantasma irreal, siente su pulso mortal idéntico, en su latido, a otro corazón que ha sido el de un sueño fantasmal.
} (BERGAMÍN (1963), 1984-85, p. 95)

\section{O retorno definitivo}

O período entre o regresso de Bergamín à Espanha e sua morte foi marcado por algumas polêmicas e pela exclusão do escritor que via com indignação o processo de transição pelo qual passava o país com o fim do franquismo. Esse descontentamento é explicado, segundo Iván López Cabello (2015), por Bergamín manter-se coerente com seu compromisso político 
republicano por mais de meio século. $\mathrm{O}$ autor ainda ressalta que o radicalismo de Bergamín em defender o republicanismo não teria outra opção que entrar em choque com o processo de transição ocorrido em meados dos anos setenta que consolidava a monarquia parlamentarista (CABELLO, 2015). Uma das principais críticas feitas por Bergamín é com relação à anistia que estavam defendendo durante a transição, segundo ele, "amnistía querrá decir, sencillamente, revisión justa y justiciera, de hecho y de derecho" (BERGAMÍN (1976) 1984-85, p. 126). Nesse sentido, o escritor espanhol ainda afirma que anistia é uma recordação vívida e não significa dar perdão a quem nunca foi culpabilizado pelos delitos cometidos. Na concepção de Bergamín, a ideia de anistia empregada era uma forma de perdoar o franquismo por todas as atrocidades cometidas, deformando o sentido original que deveria ter, isto é, de uma revisão por justiça. Como ressalta Filipe Canto (2019), a equiparação feita pela anistia levou à impunidade e ao esvaziamento político, pois dificultou o esclarecimento de certos acontecimentos igualando vencedores e vencidos. Esse processo de transição também representou o fim do projeto republicano iniciado na década de 1930, principalmente pela criação de uma nova constituição que substituiu a republicana de 1931, o que, de certa forma, explica a aversão de Bergamín ao processo de transição. Hortencia Campanella (2010) afirma que nesse período Bergamín se deu conta de que havia se tornado um fantasma preso a um passado que era incômodo, naquele momento, tanto para ele como para a Espanha, porém acreditamos que ele já tinha noção disso desde antes, como já ressaltamos.

Essa relação entre passado e presente e o problema que a transição representava para Bergamín foi expressada por ele, em um texto sobre Guernica, publicado na revista Sabádo Gráfico no dia 10 de dezembro de 1977, no qual o escritor comentou sobre como o quadro de Picasso continuava vivo, atual e também sobre como a Espanha não o merecia, assim como outros grandes nomes republicanos que vinham sendo requisitados naquele momento, como uma forma de promover uma conciliação por meio da anistia que ele criticava. Bergamín, que antes se sentia deslocado em seu país, agora se 
revoltava com a tentativa de apropriação da memória republicana que estava em curso. Assim, afirma que:

Si el "Guernica" de Picasso pertenece al pueblo español, ¿qué voz española tiene hoy su autorización representativa auténtica para reclamarlo? La única que pudiera tenerla, la del pueblo vasco, sigue imposibilitada de hacerlo; porque sigue estando ahogada en su sangre y perseguida por el terror que el "Guernica" expresa y denuncia: el del franquismo. Ya es significado que se pida la vuelta a España ahora del lienzo de Picasso por las mismas voces que piden la de los restos mortales de Antonio Machado y de Azaña. Si esta importación de cadáveres gloriosos ya es sospechosa de maniobra politiquera, y falsificadora hasta la muerte, ¿qué pensaremos de traer la pintura viva de Picasso como cómplice encubridora de la siniestra continuidad legal (!) que representa sus peticionarios? Por muy grande que sea la trampa - y lo es enorme, sin medida -, el lienzo de Picasso no cabe en ella; y habría que romperlo en pedazos para lograrlo; para anonadarlo o aniquilarlo en lo que es y en lo que representa; que de eso se trata. Pero su maravillosa violencia creemos que se basta a sí misma para impedirlo (BERGAMÍN, (1977b) 1984-85, p. 145-146).

Bergamín demonstrava o medo de um apagamento da memória da Guerra Civil e também da ressignificação dos símbolos e personagens republicanos em nome de uma transição pacífica. Trata-se do que entendia como o "exílio da história" ao qual se refere Fornerón. Expressava também o sentimento de injustiça que lhe tomava ao ver, após quase uma vida toda de exílio, a memória e os valores pelos quais lutou serem deturpados em prol dos inimigos que o expulsaram de sua terra.

Bergamín nunca deixou de ressaltar a ilegalidade pela qual se estabeleceu o governo de Franco. Isso fez com que se caracterizasse como uma voz dissidente dentro da Espanha da transição. Essa conduta explicaria, segundo Cabello (2015), porque no final da sua vida ele declarava que estava totalmente na ilegalidade, pois os padrões legais eram os de Franco e da dinastia dos Bourbons. Dentro desse contexto, Bergamín, já no final da vida, chegou a declarar apoio ao Euskadi Ta Askatasuna, popularmente conhecido como ETA, que ele via “como último reducto de la 'pureza', sino por su actitud 
sentimental de ruptura con la nueva realidad de consenso, y de cólera ante la general acpetación de la mornaquía” (CAMPANELLA, 2010, p. 97-98).

José Bergamín faleceu em 23 de agosto de 1983 na cidade de San Sebastián, um mês depois de seu amigo Luis Buñel a quem chamava de $E l$ ángel exterminador ${ }^{13}$ (CAMPANELLA, 2010, p. 98). Não temeu a morte que "apodrece o corpo", mas "a que apodrece a alma" e, talvez por isso, seguiu sendo fiel e coerente com os seus princípios e ideologias até o final da vida, mesmo que isso significasse certa exclusão social e histórica. Após a sua morte, José Luis López Aranguren (1983, n/p) afirmou em um texto para o jornal $E l$ País que não seria nenhum exagero considerar que Bergamín foi tanto nos anos da república, como também depois no que ele chama de "Espanha peregrina", o intelectual mais importante da Espanha. Afirmação forte, pois, principalmente na primeira metade do século XX, a Espanha teve nomes como os de Miguel de Unamuno e Ortega y Gasset que tiveram muita relevância. Porém, trata-se de uma avaliação que mostra a força das ideias e da trajetória desse intelectual não canônico.

No jornal El País também foi publicado um texto de seu amigo Rafael Alberti (1983), que esteve exilado na Argentina e conta que para encontrar o amigo tinha que cruzar o Rio da Prata até Montevidéu, pois o governo peronista não permitia a sua entrada em Buenos Aires. De maneira bastante fiel à trajetória do amigo, Alberti declara:

José Bergamín ha muerto como perdido, lejano, pero ejemplarmente, íntegro, en su fe, en su desilusión de tantas cosas, admirado, pero conocido, para lo extraordinario que era, no tanto como merecía; discriminado, marginado, como personaje molesto, con el que para muchos no era muy grato tropezarse (ALBERTI, 1983, n/p).

Alberti, por fim, diz que não seria adequado se despedir de Bergamín com um “descanse em paz”, pois seria impossível imaginá-lo em uma postura de descanso pacífico. Questiona-se também o rumo que tomou Bergamín após a morte, pois não tinha o perfil de quem adentraria as portas do inferno ou os

${ }^{13} \mathrm{O}$ filme homônimo de Buñel também faz referência a Bergamín, pois teria o mesmo título de uma suposta peça inacabada do escritor madrilenho. Para uma análise mais aprofundada ver: (MILES, 2005). 
portões do paraíso por se tratar de um "peregrino errante", deixando em aberto esse destino final, talvez reafirmando a natureza fantasmagórica que o amigo frequentemente reivindicava. Como despedida de Bergamín, porém, cita um trava-línguas que costumavam repetir quando se encontravam, uma despedida sem adeus e com desejo de reencontro ${ }^{14}$.

\section{Considerações finais}

Buscamos neste artigo analisar um pouco da instigante trajetória e obra de José Bergamín, autor que como pudemos ver, apesar da relevância, principalmente dentro da Espanha, terminou deixado de lado. Ainda que declarações como a supracitada de José Luis López Aranguren possam parecer bastante exageradas, Bergamín era reconhecido por outros intelectuais, principalmente durante a Guerra Civil Espanhola, como afirma Gonzalo Penalva Candela: "el escritor madrileño es, en estos momentos [se refiere a 1937], uno de los intelectuales españoles más conocidos y con más prestigio en Europa" (CANDELA apud. ABRIL, 2010, p. 74). Durante o exílio também continuou sendo um escritor importante e considerado perigoso pelo governo franquista que o manteve sob o seu radar, censurando seus livros que eram publicados na Espanha (MARCO, 2017). Acreditamos que a censura sofrida juntamente com as desavenças que foi acumulando no caminho (ainda que seus biógrafos exaltem sua coerência com os seus ideias e a sua postura combativa, Bergamín também era conhecido por suas rixas pessoais) ${ }^{15}$ corroborara o processo que o fez um escritor desconhecido mesmo dentro da Espanha. María Teresa S. M. Fernández (2015, p. 287) relata que estudou o escritor em seu doutorado e que há mais de vinte anos segue ouvindo e respondendo questões como: "Pero ¿sobre quién dices que vas a escribir tu tesis? ¿Quién es ese? ¿Bergaqué? ¿Y qué escribió? ¿Y quién lo conoce? ¿Están bien sus obras? ¿Por

\footnotetext{
${ }^{14}$ O trava-línguas citado por Alberti: Doña Dírriga, Dárriga, Dórriga, trompa pitárriga, / tiene unos guantes de pellejo de Zírriga, Zárriga, Zórriga, / trompa pitárriga, le vienen grandes. (ALBERTI, 1983, n/p).

${ }^{15}$ Além do desacordo com Manuel de Falla que tratamos neste texto, outra querela conhecida de Bergamín foi com a escritora e editora da revista Sur, Victoria Ocampo. Ver: (BERGAMÍN; OCAMPO, 1937).
} 
qué no lo conoce casi nadie? ¿De qué siglo era? ¿Tú crees que vale la pena leerlo?". Como destaca Sabina Loriga (1998, p. 248-249), a perspectiva trazida pela micro-história abriu espaço para as vidas que fogem da média, pois essas "levam talvez a refletir melhor sobre o equilíbrio entre a especificidade do destino pessoal e o conjunto do sistema social". Nesse sentido, acreditamos que a vida de Bergamín exprime essas nuances, ilustrando tanto o lugar dos intelectuais engajados com a causa republicana na Espanha como dos exilados.

A exemplo deste artigo, alguns pesquisadores vêm nos últimos anos se ocupando da trajetória e obra de Bergamín. Em 2013 ocorreu o "Colóquio Internacional Bergamín: entre literatura e política”, organizado pela Université Paris Ouest Nanterre La Défense e pela Universitat Autònoma de Barcelona em homenagem aos 30 anos de morte do escritor madrilenho. O colóquio resultou no livro publicado em 2015 intitulado: José Bergamín: entre literatura y política organizado por Max Hidalgo Nácher, Iván López Cabello e María Teresa S. M. Fernández. O livro traz, além de textos sobre a obra e diferentes momentos da vida do escritor, relatos de familiares, amigos e estudiosos que expressam em comum a admiração e a vontade de, de certa forma, "resgatar" e creditar à obra de Bergamín o reconhecimento que eles julgam merecido.

Apesar de permanecer fora do cânone composto pelos grandes nomes da intelectualidade espanhola, Bergamín deixou sua marca para a literatura e para o pensamento espanhol do século XX como intelectual engajado, poeta e crítico político, como tentamos demonstrar neste artigo. Sua trajetória também é reveladora do significado de ser um intelectual comprometido com a causa republicana espanhola, fator que impactou suas escolhas, obra e pesou para que fosse condenado ao esquecimento. A riqueza, a diversidade e a singularidade de sua obra, porém, fazem dele um dos escritores mais instigantes de sua época, não apenas no país ibérico. Há ainda muito para ser explorado em seus escritos e mesmo em sua trajetória, configurando-o como um campo aberto para pesquisadores interessados na história intelectual espanhola.

\section{Referências}


ABRIL, Juan Carlos. José Bergamín ante sí mismo. Cuadernos Hispanoamericanos, n.725, p. 73-87, 2010.

ALBERTI, Rafael. De X a X. EI País, 13 septiembre de 1983. Disponível em: https://elpais.com/diario/1983/09/14/opinion/432338411_850215.html

[Acessado em 04 de maio de 2020].

ARANGUREN, José Luis L. José Bergamín. El País, 03 de septiembre de 1983. Disponível em:

https://elpais.com/diario/1983/09/04/opinion/431474413_850215.html

[Acessado em 04 de maio de 2020].

BEEVOR, Antony. La guerra civil española. Barcelona: Editorial Crítica, 2005.

BERGAMÍN, José. De una España peregrina. Litoral, nº 145/147, p. 92-95, 1984-85.

BERGAMÍN, José. Discurso no II Congreso Internacional de Escritores para la Defensa de la Cultura. Hora de España, ${ }^{\circ}$ VIII, p. 30-36, 1937.

BERGAMÍN, José. El anteismo español de Buñuel. Litoral, $n^{\circ}$ 145/147, p. 8790, 1984-85.

BERGAMÍN, José. El caballito del diablo. Buenos Aires: Losada, 1942.

BERGAMÍN, José. El pensamiento hermético de las artes. Cruz y Raya. Año $1, \mathrm{n}^{\mathrm{o}} 1$, abril de 1933 .

BERGAMÍN, José. España, mañana.... Litoral, nº 145/147, p. 136-139, 198485.

BERGAMÍN, José. Fronteras infernales de la poesía. Madrid: Taurus, 1959.

BERGAMÍN, José. Guernica. Litoral, n 145/147, p. 143-146, 1984-1985.

BERGAMÍN, José. Hablar en cristiano. Cruz y Raya. Año 3, no 27 , julio de 1935.

BERGAMÍN, José. La decadencia del analfabetismo. Cruz y Raya. Año 1, $\mathrm{n}^{\circ}$ 3, junio de 1933.

BERGAMÍN, José. La importancia del demonio. Cruz y Raya. Año 1, n5, agosto de 1933.

BERGAMÍN, José. La mascara de sangre. Tiempo y drama. Sur, año VII, $n^{\circ}$ 28, p. 31-46, janeiro de 1937.

BERGAMÍN, José. La prueba de los amigos. Litoral, nº 145/147, p. 81-84, 1984-85.

BERGAMÍN, José. Los presos privilegiados. Litoral, $n^{\circ}$ 145/147, p. 125-129, 1984-85.

BERGAMÍN, José. Por nada del mundo (anarquismo y catolicismo). In: El pensamiento perdido. Paginas de la guerra y del destierro. Madrid: Adra, p. 41-60, 1976.

BERGAMín, José. Signo y deseño de Cruz y Raya. In: El aviso de escarmentados del año que acaba y escamiento de avisados para el que empieza de 1935. Alemanha: Bläschke \& Ducke GmbH, 1974.

BERGAMÍN, José. Volver. Litoral, nº 145/147, p. 96-97, 1984-85.

BERGAMÍN, José; FALLA, Manuel. El epistolario (1924-1935). Ed. DENNIS, Nigel. Valencia: Pre-textos, 1995. 
BERGAMÍN, José; OCAMPO, Victoria. Notas: carta abierta de José Bergamín a Victoria Ocampo - Victoria Ocampo a José Bergamín. Sur, año VII, n. 32, p. 67-74, mayo de 1937.

BERGAMÍN, José; UNAMUNO, Miguel. El epistolario (1923-1935). Ed. DENNIS, Nigel. Valencia: Pre-textos, 1993.

BOURDIEU, Pierre. A ilusão biográfica. In: FERREIRA, Marieta de Moraes; AMADO, Janaína. Usos e abusos da história oral. Rio de Janeiro: FGV, p. 183-191, 2006.

CABELLO, Iván L. "Mi mundo no es de este reino": la voz republicana y disidente de José Bergamín en la España de la transición. In: NÁCHER, M. Et al. José Bergamín: entre literatura y política. Paris: Presses Universitaires de Paris Ouest, p. 249-263, 2015.

CAMPANELLA, Hortensia. José Bergamín, las paradojas de un peregrino. Cuadernos Hispanoamericanos, n.725, p. 89-99, 2010.

CANTO, Filipe C. Aporias da memória em O Impostor, de Javier Cercas. Dissertação apresentada junto ao Programa de Pós-Graduação em História da Universidade Federal do Rio Grande do Sul para a obtenção do título de Mestre, 2019.

CHENU, Roselyne. El segundo exilio de José Bergamín. In: NÁCHER, M. Et al. José Bergamín: entre literatura y política. Paris: Presses Universitaires de Paris Ouest, p. 233-247, 2015.

CRUZ, Juan. José Bergamín: "en España me siento realmente fantasma”. EI País, 18 de abril de 1978. Disponível em: https://elpais.com/diario/1978/04/19/cultura/261784803_850215.html [Acessado em 04 de maio de 2020].

DENNIS, Nigel. José Bergamín a critical introduction 1920-1936. Toronto: Univesity of Toronto Press, 2017.

ELIAS, Nobert. Mozart: sociologia de um gênio. Rio de Janeiro: Zahar, 1994. FERNÁNDEZ, María Teresa S. M. et. al. Collectif d'auteurs. In: NÁCHER, M. Et al. José Bergamín: entre literatura y política. Paris: Presses Universitaires de Paris Ouest, p. 283-344, 2015.

FERNÁNDEZ, María Teresa S. M. La trilogía dramática sobre la guerra civil. In: NÁCHER, M. Et al. José Bergamín: entre literatura y política. Paris: Presses Universitaires de Paris Ouest, p. 99-118, 2015.

FORNERÓN, Ivan Martucci. Três poetas e três tempos do exílio espanhol de 1939. Luis Cernuda, Emilio Prados e Max Aub. Tese apresentada junto ao Programa de Pós-Graduação em Letras Modernas da Universidade de São Paulo para a obtenção do título de Doutor. 2015.

LEVI, Giovanni. Usos da biografia. In: FERREIRA, Marieta de Moraes; AMADO, Janaína (Orgs). Usos e abusos da história oral. Rio de Janeiro: FGV, p. 167-182, 2006.

LÓPEZ, Yasmina Y. Al volver (1962): el regreso de José Bergamín. In: NÁCHER, M. Et al. José Bergamín: entre literatura y política. Paris: Presses Universitaires de Paris Ouest, p. 151-161, 2015.

LORIGA, Sabina. A biografia como problema. In: REVEL, Jacques (Org.). Jogos de escalas: a experiência da microanálise. 
MACHADO, Antonio. Miscelánea apócrifa. Hora de España, año 2, nº XIII, p. 7-16, enero de 1938.

MARCO, Valeria. Ojo con Cernuda y Bergamín: vigilancia literaria durante el franquismo. Creneida, $n^{\circ}$ 5, p. 125-138, 2017. Rio de Janeiro: FGV, p. 225250, 1998.

MILES, Robert. Crossing the line in Mexico? Luis Buñuel's El ángel exterminador. In: SHAW, Lisa; DENNISON Stephanie (eds). Latin American Cinema: Essays on modernity, gender and national identity. North Carolina and London: McFarland, p. 59-90, 2005.

OTTO, Walter. Los dioses de Grecia. Madrid: El Árbol del Paraíso, 2003.

PAPA PIO XI. Carta encíclica Divinis Redemptoris de sua Santidade Papa

Pio XI aos veneráveis irmãos, patriarcas, primazes, arcebispos, bispos e demais ordinários em paz e comunhão com a sé apostólica sobre o comunismo ateu. 19 de março de 1937. Disponível em: https://w2.vatican.va/content/pius-xi/pt/encyclicals/documents/hf_pxi_enc_19370319_divini-redemptoris.html [consultado em 04 de maio de 2020].

PENALVA, Gonzalo. Tras las huellas de un fantasma. Aproximación a la vida y obra de José Bergamín. Madrid: Turner, 1985.

PEREIRA, Douglas de Freitas. José Bergamín, Cayetano Córdova Iturburu e o engajamento intelectual antifascista na Espanha e na Argentina durante a década de 1930. Dissertação de mestrado apresentada junto ao Programa de Pós-Graduação em História Social da Universidade de São Paulo para a obtenção do título de Mestre. 2019.

SCHNEIDER, Luis Mario. II Congreso internacional de escritores para la defensa de la cultura (1937): inteligencia y guerra civil española. Valência: Generalitat Valenciana, 1987.

UNAMUNO, Miguel. Comentario de Miguel de Unamuno. Nuevo Mundo, año XXXI, no 1572, 7 de marzo, 1924.

ZAMBRANO, María. Antonio Machado y Unamuno, precursores de Heidegger. Sur, año VIII, no 42, p. 85-86, marzo de 1938.

Recebido em: 07 de junho de 2020

Aceito em: 14 de julho de 2021 